\title{
ASAS ULTIMUM REMIDIUM DALAM PENEGAKAN HUKUM ADMINISTRASI PERLINDUNGAN DAN PENGELOLAAN LINGKUNGAN HIDUP
}

\author{
Oleh : Dindin M Hardiman, S.Sos. M.M., M.H. ${ }^{\star}$
}

\begin{abstract}
Abstrak
Penegakan hukum lingkungan dapat dilakukan secara preventif dan represif, sesuai dengan sifat dan efektivitasnya. Penegakan hukum yang bersifat preventif, berarti bahwa pengawasan aktif dilakukan terhadap kepatuhan kepada peraturan tanpa kejadian langsung yang menyangkut peristiwa konkrit. Instrumen bagi penegakan hukum preventif adalah penyuluhan, pemantauan dan penggunaan kewenangan yang sifatnya pengawasan (pengambilan sampel, penghentian mesinmesin dan sebagainya). Penegakan hukum lingkungan yang bersifar represif dilakukan dalam hal perbuatan yang melanggar peraturan dan bertujuan untuk mengakhiri secara langsung perbuatan terlarang. Untuk menghindari penindakan pidana secara berulang-ulang, pelaku sendirilah yang harus menghentikan keadaan itu.

Pendekatan penegakan hukum lingkungan di indonesia dapat ditempuh dengan empat cara pendekatan, yaitu : Pendekatan Command And Control (CAC), pendekatan ekonomi, pendekatan perilaku (behaviour), pendekatan pendayagunaan tekanan publik (public pressure). Penegakan hukum administrasi. Asas subsidiritas (di dalamnya terdapat asas precautionary) dan asas ultimum remidium sangat berkaitan erat dengan penegakan hukum administrasi.
\end{abstract}

Kata Kunci: Asas Ultimum Remidium, penegakan hukum lingkungan, hukum administrasi.

\footnotetext{
*) Dosen Fakultas Hukum Universitas Galuh
} 


\begin{abstract}
Environmental law enforcement can be done in a preventive and repressive, according to the nature and effectiveness. Preventive law enforcement, means that the active supervision conducted on compliance with regulations without incident directly involving concrete events. Instruments for preventive law enforcement is education, monitoring and use its powers of supervision (sampling, termination machines and so on). Enforcement of environmental laws bersifar done in terms of repressive acts that violate the rules and aims to put an end to direct forbidden. To avoid criminal prosecution repeatedly, the perpetrator himself who must stop the situation

Approach to environmental law enforcement in Indonesia can be reached by four approaches, namely: Approaches Command And Control (CAC), the economic approach, the behavioral approach (behavior), utilization of public pressure approach (public pressure). Administrative law enforcement. Subsidiritas principle (in which there is the precautionary principle) and the principle of ultimum remedium are intimately associated with the administrative law enforcement.
\end{abstract}

Keywords: Principles Subsidiritas and ultimium remedium, enforcement of environmental law, administrative law, criminal law. 


\section{Pendahuluan}

Penegakan hukum (law enforement), merupakan suatu istilah yang mempunyai keragaman pengertian. Menurut Satjipto Rahardjo, penegakan hukum diartikan sebagai suatu proses untuk mewujudkan keinginankeinginan hukum, yaitu pikiran-pikiran dari badan-badan pembuat undang-undang yang dirumuskan dan ditetapkan dalam peraturanperaturan hukum yang kemudian menjadi kenyataan. (Satjipto Rahardjo, 1993: 15)

Sedangkan Soedarto mengartikan penegakan hukum sebagai perhatian dan penggarapan perbuatan melawan hukum yang sungguh- sungguh terjadi (onrecht in actu) maupun perbuatan melawan hukum yang mungkin terjadi (onrecht in polentie) (Soedarto,1986:111). Hal senada dikatakan oleh Soerjono Soekanto, yang mengemukakan bahwa :

"Kegiatan untuk menyerasikan hubungan nilai-nilai yang terjabarkan dalam kaedah-kaedah yang mantap dan pengejawantahan dalam sikap dan tindakan sebagai rangkaian penjabaran nilai-nilai tahap akhir, untuk menciptakan dan memelihara, serta mempertahankan kedamaian dan pergaulan. Secara kosepsional maka inti dan arti penegakan terletak pada pergaulan hidup". (Soerjono Soekanto:1993:5)

Demikian pula dirumuskan dalam Laporan seminar Hukum Nasional ke-4, bahwa : "Penegakan hukum adalah keseluruhan kegiatan dari para pelaksana penegak hukum, keadilan, dan perlindungan terhadap harkat dan martabat manusia, ketentraman, dan kepastian hukum, sesuai dengan UU 1945. (Barda Nawawi Arief: 1998: 8) keberhasilan penegakan hukum pada dasarnya dipengaruhi oleh beberapa faktor, dimana faktor-faktor ini mempunyai hubungan yang erat dan saling mempengaruhi antara satu dengan lainnya. Menurut Soerjono Soekanto, faktor-faktor tersebut adalah : (Soerjono Soekanto: 58:5)

a) Faktor hukumnya sendiri;

b) Faktor penegak hukum, yang meliputi aparat ataupun lembaga yang membentuk dan menerapkan hukum;

c) Faktor sarana pendukung penegakan hukum;

d) Faktor masyarakat; 
e) Faktor kebudayaan, yakni sebagai hasil karya cipta dan rasa yang didasarkan pada manusia dan pergaulan hidup.

Penegakan Hukum Lingkungan berkaitan erat dengan kemampuan aparatur dan kepatuhan warga masyarakat terhadap peraturan yang berlaku, yang meliputi tiga bidang hukum, yaitu administratif, pidana, dan perdata.

Berdasarkan pendapat di atas, maka penegakan hukum lingkungan dapat dilakukan secara preventif dan represif, sesuai dengan sifat dan efektivitasnya. Penegakan hukum yang bersifat preventif, berarti bahwa pengawasan aktif dilakukan terhadap kepatuhan kepada peraturan tanpa kejadian langsung yang menyangkut peristiwa konkrit yang menimbulkan sangkaan bahwa peraturan hukum telah dilanggar. Instrumen bagi penegakan hukum preventif adalah penyuluhan, pemantauan dan penggunaan kewenangan yang sifatnya pengawasan (pengambilan sampel, penghentian mesin-mesin dan sebagainya). Dengan demikian, penegak hukum yang utama adalah pejabat/aparat pemerintah yang berwenang memberi izin dan mencegah terjadinya pencemaran lingkungan. Penegakan hukum lingkungan yang bersifar represif dilakukan dalam hal perbuatan yang melanggar peraturan dan bertujuan untuk mengakhiri secara langsung perbuatan terlarang. Penindakan secara pidana umumnya selalu menyusuli pelanggaran peraturan dan biasanya tidak dapat meniadakan akibat pelanggaran tersebut. Untuk menghindari penindakan pidana secara berulang-ulang, pelaku sendirilah yang harus menghentikan keadaan itu.

Dengan meningkatkan faktor-faktor pendukung efektifitas penegakan hukum tersebut, maka akan dapat diciptakan suasana yang kondusif bagi penegakan hukum lingkungan tersebut dapat dilakukan dengan berbagai cara, antara lain yaitu dengan cara : (Harun M Husein, 1993. Hal. 223-225)

a) deregulasi hukum lingkungan;

b) pembinaan kesamaan persepsi antar penegak hukum;

c) melengkapi sarana dan fasilitas; dan

d) pembinaan kesadaran hukum masyarakat.

Guna menunjang terlanjutkannya pembangunan yang berwawasan lingkungan, maka dalam penegakan hukum lingkungan teknik pendekatan terhadap masalah pelanggaran ketentuan pengelolaan lingkungan harus 
menggunakan teknik pendekatan komprehensive-integral. Menurut Michael Hegar, fungsi hukum sebagai sarana pembangunan berlaku dalam tiga sektor, yaitu : (Ronny Hanitijo Soemitro, 1979: 36)

a) Hukum sebagai alat penertib (ordening);

b) Hukum sebagai alat penjaga keseimbangan (balancing); dan

c) Hukum sebagai katalisator.

Hukum sebagai alat penertib, ialah hukum yang mampu menciptakan suatu kerangka bagi pengambilan keputusan politik dan penyelesaian sengketa yang mungkin dilakukan melalui suatu hukum acara yang baik, sehingga dapat diletakan suatu dasar hukum bagi penggunaan kekuasaan. Hukum dapat pula berfungsi sebagai alat atau sarana penjaga keseimbangan antara kepentingan umum dan kepentingan masing-masing pribadi, sedangkan peran hukum sabagai katalisator adalah sebagai pembantu untuk memudahkan terjadinya proses perubahan melalui pembangunan hukum dengan bantuan tenaga hukum yang mampu bersaing. Dengan demikian, hukum berperan sebagai sarana pengawal dan pengaman pelaksanaan pembangunan.

\section{Pembahasan}

\subsection{Penegakan Hukum Lingkungan Hidup}

Sebagaimana dikatakan oleh Mas Achmad dalam uraian di atas, bahwa tujuan dari penegakan hukum lingkungan esensinya adalah (compliance) terhadap nilai-nilai perlindungan daya dukung ekosistem dan fungsi lingkungan hidup. Untuk mencapai penataan tersebut, maka sesungguhnya penegakan hukum bukanlah satu-satunya cara. Karena berbagai cara atau pendekatan dapat dilakukan antara lain melalui instrumen ekonomi, edukasi, bantuan teknis dan tekanan publik (public pressure).

Secara garis besar pendekatan penataan dapat ditempuh melalui 4 (empat) pendekatan, yaitu: (Mas Achmad Santosa: 234-235).

a. Pendekatan Command and Control (CAC).

b. Pendekatan ekonomi.

c. Pendekatan perilaku. 
d. Pendekatan pendayagunaan tekanan publik (public pressure)

Pendekatan penjeraan (deterent approach) atau lazim disebut dengan pendekatan command and control atau pendekatan penegakan hukum atau stick (vis a vis pendekatan carrot). Pendekatan ini paling banyak digunakan dalam kebijakan penegakan hukum lingkungan. Penjeraan atau deterent ini dapat berupa ancaman hukuman (sanksi) atau penjatuhan sanksi.

Deterrent dapat bersifat khusus atau spesifik yaitu berupa mencegah agar pelaku pelanggaran tidak melakukan pelanggaran yang sama. Dan dapat pula bersifat umum yaitu berupa pencegahan agar masyarakat umum tidak melakukan pelanggaran yang sama.

Pendekatan penjeraan ini baru dapat berlaku efektif manakala minimal terdapat 3 (tiga) prakondisi sebagi berikut :

1. Kemampuan mendeteksi adanya pelanggaran.

2. Tanggapan (respons) yang cepat dan pasti (swift \& sure responses) terhadap pelanggaran yang dideteksi sebagaimana pada angka 1 di atas.

3. Sanksi yang memadai.

Indonesia sebagai negara yang menerapkan sistem pendekatan penjeraan atau CAC menurut Mas Achmad Santosa (Mas Achmad Santosa, 2001) menghadapi masalah serius, karena pada dasarnya Indonesia tidak memiliki sistem pengawasan penataan, penanggapannya sangat inkonsisten dan cenderung indiskriminatif, serta penjatuhan sanksi administratif maupun pidana terhadap penanggung jawab kegiatan yang melanggar hukum jarang diberlakukan.

Pendekatan ekonomi, didasarkan pada suatu dalil bahwa setiap penanggung jawab kegiatan yang berpotensi mencemarkan, secara rasional akan menghitung terlebih dahulu sejauhmana penataan (compliance) atau melakukan pelanggaran (violation) mendatangkan keuntungan secara ekonomi. Teori inilah yang memberi dasar bagi pengembangan instrumen ekonomi dalam pengendalian dampak lingkungan. 
Pendekatan perilaku (behaviour) menekankan pada human motivation dengan penekanan pada pentingnya kerjasama melalui perundingan/ negosiasi, upaya meyakinkan regulated community tentang pentingnya penataan, pemberian dukungan/bantuan teknis agar masyarakat industri bersedia mengikuti program penataan. Hubungan personal (personal relationship) antara objek pengaturan (regulated community) dan aparat pemerintah (regulator) sebagai sesuatu yang sangat penting dan merupakan prakondisi untuk mewujudkan kondisi taat. Model ini memandang industri sebagai objek pengaturan yang incompetent atau unknowledgeable.

Pendekatan tekanan publik (public pressure) menekankan pada pentingnya kekuatan masyarakat, termasuk masyarakat korban (affected community) melalui berbagai tekanan yang dilakukan, seperti unjuk rasa, kampanye, media massa, maupun boikot dari usaha yang melanggar nilai-nilai perlindungan lingkungan yang tujuannya agar penanggungjawab usaha melakukan upaya-upaya compliance.

Pengunaan pendekatan-pendekatan di atas berbeda antara satu negara dengan negara lainnya, sangat tergantung kepada situasi kondisi pemahaman pemerintah, kultur birokrasi, dan kehendak politik dan komitmen pemerintah.

Suatu norma atau suatu aturan yang berbentuk perundangundangan dimaksudkan oleh pembentuk Undang-undang (legislator) agar dapat dijadikan pedoman dan acuan bertindak bagi masyarakat luas. Agar supaya suatu perundang-undangan tersebut dapat ditaati atau dipatuhi oleh masyarakat, maka diberikan sanksi, baik sanksi yang bersifat negatif bagi pelanggar ketentuan berupa nestapa yang diberikan bagi si pelanggar, dan sanksi yang bersifat positif berupa penghargaan bagi yang menaatinya.

\subsection{Asas Ultimum Remidium dalam penegakan hukum administrasi perlindungan dan pengelolaan lingkungan hidup.}

Asas ultimum remidium berkaitan erat dengan delik formal, dan delik formal adalah delik yang berkaitan dengan hukum administrasi. 
Sedangkan makna penegakan hukum lingkungan (environmental enforcement) harus dimaknai sebagai sebuah alat (a means) untuk meraih sebuah tujuan (an end). Dimana tujuan penegakan hukum lingkungan adalah penataan (compliance) terhadap nilai-nilai perlindungan daya dukung ekosistem dan fungsi lingkungan hidup.

Hal ini sejalan dengan penegakan hukum lingkungan di Amerika Serikat (Mardjono Reksodiputro: 1982), dimana mata rantai penegakan hukum yang panjang tersebut menempatkan hukum administrasi berada pada prioritas utama, dan penegakan hukum pidana ditempatkan pada akhir dari proses penegakan hukum lingkungan ini. Mata rantai tersebut dikelompokkan sebagai berikut :

a. Penentuan kebijakan, desain dan perencanaan, pernyataan dampak lingkungan.

b. Peraturan tentang standar atau pedoman minimum, prosedur perizinan.

c. Keputusan administrasi terhadap pelanggaran, penentuan tenggang waktu dan hari terakhir agar peraturan ditaati.

d. Gugatan perdata untuk mencegah atau menhambat pelanggaran, penilaian terhadap denda atau ganti kerugian.

e. Gugatan masyarakat untuk memaksa atau mempercepat pemerintahan mengambil tindakan, gugatan ganti kerugian.

f. Tuntutan pidana.

Menurut Mas Achmad Santosa (Mas Achmad Santosa: 174-177) ketidakberdayaan dalam pengelolaan lingkuan hidup kuncinya adalah dalam penegakan hukum. Dalam hal ini menurutnya sebagian besar disebabkan oleh faktor yang bersifat struktural dan sedikit bersifat teknis.

Faktor struktural yang utama adalah masih dominannya pemikiran dikalangan penentu kebijakan yang mempertentangkan antara pembangunan dan lingkungan (pembangunan versus lingkungan). Juga belum sepenuhnya tercipta good governance yang memustahilkan penegakan hukum lingkungan yang efektif, karena 
kedekatan antara pengawas (regulator) dan yang diawasi (regulates) yang membiarkan pelanggaran.

Faktor teknis misalnya masalah pembuktian dan kurang terampilnya aparat penegak hukum.

Penegakan hukum administrasi seyogyanya mulai dioperasionalkan semenjak suatu usaha atau kegiatan mulai memajukan izin usaha (tindakan preventif). Hal ini sejalan dengan ketentuan Pasal 1 angka 2 (Pasal 1 angka 2, Undang-Undang Nomor 23 Tahun 1997). dari Undang-undang Nomor 23 Tahun 1977 tentang pengelolaan Lingkungan Hidup yang lebih mendahulukan upaya pencegahan. Oleh karena itu harus diperhatikan instrumen preventif sebelum diberikan izin atas suatu usaha atau kegiatan, seperti : (Hambar Martono: 243-244).

1. Setiap usaha atau kegiatan harus dilakukan sesuai dengan tata ruang agar sesuai dan serasi dengan daya dukung dan daya tampung lingkungan.

2. Setiap usaha atau kegiatan wajib memperoleh izin lokasi.

3. Wajib AMDAL, bagi usaha atau kegiatan yang diperkirakan mempunyai dampak besar dan penting terhadap lingkungan.

4. Persetujusn AMDAL, sebagai dasar menerbitkan izin melakukan usaha atau kegiatan.

Izin-izin yang berkaitan dengan pengendalian lingkungan seperti misalnya izin $\mathrm{HO}$ (Ordonansi gangguan) dan izin pembuangan limbah cair ternyata dalam praktiknya belum dioptimalkan pendayagunaannya sebagai pengendali pencemaran maupun kerusakan lingkungan. Dalam studinya Kantor Menteri Lingkungan Hidup dan EMDI tahun 1991 (Mas Achmad Santosa: 195) dinyatakan, bahwa umumnya izin-izin HO yang telah diterbitkan ternyata tidak memuat ketentuan-ketentuan tentang kegiatan pemantauan yang harus dilakukan oleh pemegang izin $\mathrm{HO}$ (self monitoring), dan kalaupun ada pada prakteknya persyaratan tersebut bersifat sangat umum.

Studi tadi menyimpulkan pula bahwa instansi-instansi pemberi izin pada umumnya tidak memiliki program pengawasan dan pemantauan yang terencana dan terprogram dengan baik. Kegiatan 
pengawasan, pemeriksaan, dan pemantauan biasanya baru dilakukan setelah timbul permasalahan tentang pencemaran atau perusakan lingkungan.

Aparat yang mengeluarkan izin yang berkaitan dengan pengelolaan lingkungan hidup seperti izin usaha, izin tempat usaha berdasarkan Ordonansi Gangguan, izin pembuangan limbah, izin mengenai pengelolaan limbah B3 harus sekaligus berfungsi sebagai pembina dan pengawas. Setiap izin yang dikeluarkan harus ditindaklanjuti dengan kegiatan pembinaan, pemberian petunjuk dan teguran untuk senantiasa mentaati persyaratan yang telah ditentukan.

Lemahnya fungsi pengawasan dan pemantauan ini oleh instansi terkait serta kurang tanggapnya aparatur dalam menangani masalah persoalan lingkungan menjadikan pendayagunaan hukum administrasi sangat lemah sekali peranannya. Oleh karena itu harus diciptakan satu sistem kelembagaan yang efisien dan efektif mulai dari tingkat pusat sampai daerah yang profesional.

Pemantauan dan pengawasan terhadap suatu usaha atau kegiatan dapat dijalankan secara intern atau self monitoring dengan melpaorkan hasilnya ke instansi terkait dan bersifat terbuka bagi masyarakat. Pengawasan terpenting dilakukan oleh pejabat pengawas atau inspektur dari instansi pemberi izin. Pengawasan dilakukan terhadap tingkat penaatan penanggungjawab usaha atau kegiatan terhadap ketentuan perundang-undangan, hal ini perlu dilakukan untuk mencegah secara dini terjadinya pelanggaran yang berakibat tercemar atau rusaknya lingkungan. Apabila instansi pemeberi izin gagal dalam melakukan pengawasan, maka pengawasan kedua adalah instansi propinsi atau pemerintah pusat.

Pengawasan eksternal lainnya adalah dilakukan oleh publik. Terhadap penanggungjawab usaha apabila tetap tidak mematuhi ketentuan peraturan perundang-undangan yang berlaku, dapat dikenai tindakan atau sanksi administrasi maupun sanksi pidana.

Pengawasan dimaksud dilakukan melalui dua jalur, yaitu pengawasan aktif dan pengawasan pasif, pada pengawasan tim terjun langsung ke lapangan mengamati dan mengambil sampel untuk 
diperiksa di laboratorium. Pengawasan aktif dilakukan 1 atau 2 kali dalam setahun, namun dalam keadaan tertentu dapat dilakukan lebih dari 2 kali setahun, hal ini dilakukan mengingat biaya laboratorium cukup mahal. Sebaliknya pengawasan pasif dilakukan berdasarkan adanya laporan dari masyarakat atau bila terekspos di mass media.

Sesungguhnya di tingkat pusat atau nasional, pengelolaan lingkungan hidup dilaksanakan secara terpadu di bawah koordinasi Menteri Negara Lingkungan Hidup. Selanjutnya di tingkat daerah dibentuklah Bapedalda-Bapedalda untuk efektifftas pelaksanaan tugasnya tersebut. Namun demikian menurut Mas Achmad Santosa (Mas Achmad Santosa: 110), pelaksanaan pengawasan di daerah terjadi duplikasi antara lembaga Bapedalda dan instansi sektoral yang merasa memiliki fungsi kewenangan pengawasan yang sama, sehingga yang terjadi justru tidak efektif.

Mas Achmad Santosa selanjutnya mempertanyakan, dengan tidak berfungsinya izin-izin yang berkaitan dengan pengendalian dampak lingkungan tersebut, bagaimana mekanisme pemantauan dan pengawasan yang dilakukan oleh Instansi yang berwenang tersebut.

Hanya saja menurut Mas Achmad Santosa, berdasarkan pengalaman institusi yang berwenang mengeluarkan izin sekaligus yang berwenang melkukan tindakan administratif tidak memiliki kegiatan pengawasan dan pemantauan yang terencana dan terprogram dengan baik. Kegiatan pengawasan, pemeriksaan dan pemantauan baru dilakukan setelah timbul keluhan dari masyarakat tentang adanya pencemaran atau kerusakan lingkungan. Kelemahan utama penegakan hukum administrasi lingkungan menurut Wisandana adalah tidak adanya Protap (Program Tetap) yang baku, sehingga tidak ada standarisasi prosedur penegakan hukum administrasi lingkungan.

Demikian pula dari aspek hukum perdata masih banyak kendala yang menyebabkan terhambatnya penyelesaian sengketa lingkungan, seperti misalnya tidak adanya kelembagaan khusus di tingkat daerah yang memiliki mandat khusus untuk menerima dan menangani pengaduan masyarakat, tidak adanya prosedur serta mekanisme pengaduan, penelitian dan penuntutan ganti kerugian dalam kasus 
pencemaran atau perusak lingkungan, tidak adanya wadah penyedia jasa penyelesaian sengketa (service provider) di luar Pengadilan, serta keterbatasan akses masyarakat korban maupun kelompok kepentingan ke lembaga Pengadilan.

Dengan lemahnya penegakan hukum administrasi ini menurut Mas Achmad Santosa (Mas Achmad Santosa: 197-199) sangat berpengaruh terhadap efektifitas penegakan hukum pidana. Apabila penegakan hukum administrasi didayagunakan secara benar, maka catatan-catatan (record) tingkat penataan suatu kegiatan yang dihimpun secara periodik akan sangat membantu proses penyidikan, terutama dalam menentukan unsur elemen mental (mens area) dari seseorang yang diduga melakukan perbuatan pidana lingkungan.

Dari hasil penelitian yang penulis lakukan khususnya terhadap perkara pidana lingkungan yang disidangkan di Pengadilan Negeri Bale Bandung, nampak jelas bahwa fungsi hukum administrasi dalam penanganan pelanggaran ketentuan peraturan perundang-undangan oleh aparat hukum administrasi tidak berjalan sesuai dengan harapan, demikian pula persepsi aparat penegak hukum pidana terhadap pelanggaran peraturan perundang-undangan ini pun selalu menempatkan hukum pidana pada fungsi primum remidium.

Untuk memperoleh gambaran tentang Instansi atau pihak manakah yang seharusnya berwenang menyatakan suatu tindakan administrasi tidak efektif atau disfungsional, dan untuk itu penegakan hukum pidana terhadap delik formil dapat dimulai. Menurut Koesnadi pernyataan tidak efektif tersebut harus dinyatakan oleh penyidik setelah mendapat masukan dari institusi yang menangani penegakan hukum administrasi. Hal ini diperlukan karena penyidiklah yang mulai melakukan penyidikan pencemaran atau perusakan lingkungan hidup.

Demikian pula dikatakan, untuk mengukur efektifitas suatu penanganan harus minta pendapat saksi ahli. Namun ketika peneliti menanyakan siapa saksi ahli atau instansi mana yang dianggap berwenang menyatakan suatu tindakan administrasi atau perdata sudah tidak efektif lagi, beliau kurang memberikan jawaban yang pasti, silahkan aparat penyidik yang menentukannya. 
Peranan instansi terkait, misalnya Dinas Lingkungan atau Bapedalda sangat penting dalam penegakan hukum administrasi ini, karena instansi itulah yang bertugas melakukan tugas pembinaan dan pengawasan serta melakukan kontrol secara kontinyu terhadap pembuangan limbah suatu industri atau suatu usaha dan bagi yang melanggar dikenakan sanksi administrasi. Dan instansi inilah yang paling dini mengetahui adanya pembuangan limbah di atas baku mutu lingkungan.

Pendayagunaan hukum administrasi atau penegakan hukum administrasi ini berkaitan dengan penegakan hukum lingkungan oleh lembaga pemerintah (eksekutif), yang dilakukan oleh instansi yang terkait dengan lingkungan hidup, terutama oleh instansi pemberi izin atas suatu kegiatan atau usaha. Peran optimal dari instansi terkait dalam penerapan sanksi administrasi sangat diharapkan. Namun harapan terhadap aparat penegak hukum administrasi (rezim perizinan agar dapat bekerja secara lebih efektif dan efisien terhadap pelanggaran perizinan, ternyata tidak atau kurang dapat diandalkan.

Dari fakta yang terjadi, peranan penegakan hukum administrasi merupakan titik terlemah dalam penegakan hukum lingkungan, karena bila peran aparat penegak hukum administrasi bekerja dengan optimal, maka kerusakan dan/atau pencemaran lingkungan telah dapat dicegah secara dini.

\section{Kesimpulan}

Pendekatan penegakan hukum lingkungan di Indonesia dapat ditempuh dengan empat cara pendekatan, yaitu :

a. Pendekatan Command And Control (CAC).

b. Pendekatan ekonomi.

c. Pendekatan perilaku (behaviour).

d. Pendekatan pendayagunaan tekanan publik (public pressure).

Penegakan hukum administrasi sangat berpengaruh terhadap efektifitas penegakan hukum pidana. Apabila penegakan hukum administrasi didayagunakan secara benar, maka catatan-catatan (record) tingkat penataan 
suatu kegiatan yang dihimpun secara periodik akan sangat membantu proses penyidikan, terutama dalam menentukan unsur elemen mental (mens rea) dari seseorang yang diduga melakukan perbuatan pidana lingkungan.

Fungsi hukum administrasi dalam penanganan pelanggaran ketentuan peraturan perundang-undangan oleh aparat hukum administrasi tidak berjalan sesuai dengan harapan, demikian pula persepsi aparat penegak hukum pidana terhadap pelanggaran peraturan perundang-undangan ini pun selalu menempatkan hukum pidana pada fungsi primum remidium.

Asas ultimum remidium berkaitan dengan delik formal, dan delik formal adalah delik yang berkaitan dengan hukum administrasi. 


\section{Daftar Pustaka}

Barda Nawawi Arief, Beberapa Aspek Kebijakan Penegakan dan Pengembangan Hukum Pidana, Citra Aditya, Bandung, Cetakan ke-1, 1998.

Harun M. Husein, Lingkungan Hidup, Masalah, Pengelolaan, dan Penegakan Hukumnya, Bumi Aksara, Jakarta, 1993.

Mardjono Reksodiputro, Tinjauan Terhadap Perkembangan Delik-Delik Khusus Dalam Masyarakat yang Mengalami Modernisasi, Seminar Perkembangan Delik-Delik Khusus Dalam Masyarakat Yang Mengalami Modernisasi, Binacipta, Bandung, 1982.

Mas Achmad Santosa, Penegakan Hukum Lingkungan Administrasi, Pidana, Dan Perdata Berdasarkan Sistem Hukum Indonesia, Environmental Law And Enforcement Training Project Phase II, Jakarta 05-10 Nopember 2001.

Moh. Nazir, Metode Penelitian, Ghalia Indonesia, Jakarta, 2003.

Ronny Hanitijo Soemitro, Perspektif Sosial Dalam Pemahaman Masalah-Masalah Hukum Dalam Pembangunan di Indonesia., Alumni, Bandung, 1979.

Satjipto Rahardjo, Masalah Penegakan Hukum, Suatu Tinjauan Sosiologis, Sinar Baru, Bandung, 1993.

Soedarto, Kapita Selekta Hukum Pidana, Alumni, Bandung, Cetakan Ke-2, 1986.

Soerjono Soekanto, Faktor-Faktor yang Mempengaruhi Penegakan Hukum, Raja Grafindo Persada, Jakarta, Cetakan Ke-3, 1993. 